\title{
TENDENTIEUZE VOORSTELLINGEN IN DE LEER VAN DE SOCIALE ORGANISATIE
}

Kritische opmerkingen over enkele opgangmakende visies door W. F. van Eekelen, psych.drs.

\section{Inleiding}

In brede kringen is de interesse voor de sociale kant van het organisatiegebeuren groeiende. Velen hebben in hun beroep te maken met mensen die in organisatorisch verband werken en met de problemen die hieraan inherent zijn. Het is begrijpelijk dat zij belangstelling hebben voor wat de beoefenaars van de sociale wetenschappen over deze problemen te zeggen hebben.

Evenals in andere wetenschappen blijkt dat daarbij de voorkeur uitgaat naar literatuur waarin de zaken ongekompliceerd worden voorgesteld. Vooral theorieën waarin met eenvoudige tegenstellingen wordt gewerkt, zijn en vogue.

Van deze theorieën zullen vier van de bekendste hier kritisch worden besproken.

Centraal staan daarbij de beschouwingen van Argyris en Mc Gregor. Deze auteurs genieten momenteel in Nederland een grotere bekendheid dan de meeste andere onderzoekers op het gebied van de sociale-organisatieleer. Zo worden in het recent verschenen boekje „Psychologic van het bedrijf” van Van Grunsven, onder ,nieuwere inzichten” over mens en organisatie, alleen de theorieën van deze onderzoekers uitvoerig behandeld ${ }^{1}$ ). Dezelfde auteurs worden als enigen genoemd in een pleidooi van Van de Graaf voor een betere kennisname van de moderne literatuur over bedrijfspsychologie. Van de Graaf konstateert, dat de Nederlandse efficiency-ingenieur - blijkbaar in tegenstelling tot de Nederlandse psycholoog Argyris en Mc Gregor „wel kent” "2).

Uiteraard zijn Argyris en Mc Gregor niet de eerste onderzoekers die zich met sociaal-organisatorische problemen hebben beziggehouden. Ook zijn zij niet de cerste onderzoekers die van eenvoudige tegenstellingen zijn uitgegaan. Hun beschouwingen vinden qua vorm en qua inhoud een voorloper in die van Lcwin en zijn medewerkers. Qua vorm is er overeenkomst, omdat ook Lewin een eenvoudige tegenstelling als uitgangspunt van zijn bekendste onderzoekingen heeft gekozen, nl. die tussen demokratisch en autokratisch leiderschap. Qua inhoud is er overeenstemming, omdat verschillende zienswijzen van Lewin in de theorieën van Argy ris en Mc Gregor zijn terug te vinden.

Aangezien de onderzoekingen uit de school van Lewin in de literatuur - ook in de Nederlandse - veelvuldig worden geciteerd, zal hier aan de artikelen over Argyris en Mc Gregor een beschouwing over Lewin's opvattingen en werkwijze vooraf gaan. Bedoeld is daarmee tevens de theoricën van Argyris en Mc Gregor in een historisch perspektief te plaatsen.

Als laatste artikel zal in deze reeks een beschouwing komen over de tegenstelling statische en dynamische aanpak in de organisatie. Over deze tegenstelling is in de laatste jaren vooral in Nederland het één en ander geschreven. Om niet de indruk te wekken dat het lanceren van eenvoudige tegenstellingen een bij uitstek Amerikaanse aangelegenheid is en omdat de tegenstelling statisch-dynamisch nauw verband houdt met de drie eerder besproken tegenstellingen, lijkt het gewenst ook hieraan aandacht te besteden. 


\section{DE TEGENSTELLING DEMOKRATISCH-AUTOKRATISCH LEIDERSCHAP}

\subsection{Historische achtergrond}

De tegenstelling demokratisch-autokratisch, in de politiek en staatswetenschap reeds lang een zeer geliefd onderwerp, is vlak vóór de tweede wereldoorlog de sociale-organisatieleer binnengekomen door onderzoekingen uit de school van Lewin.

Lewin was één der Europese geleerden die tussen de beide wereldoorlogen naar Amerika zijn getrokken. Aanvankelijk werkte hij in Duitsland en Polen, waar hij een aanhanger was van de zg. Gestalt-psychologie. Als zodanig nam hij stelling tegen de oudere, naar natuurwetenschappelijk voorbeeld opgezette „elementenpsychologie". Terwijl het ideaal van de laatstgenoemde psychologie was het gekompliceerde psychische gebeuren van het eenvoudige uit te benaderen, meenden de Gestalt-psychologen dat bij veel psychische gedragingen de opbouw - de ,gestalte" - van het geheel primair is en dat de onderdelen slechts betekenis krijgen door de plaats die zij in een geheel innemen. De meeste Gestalt-psychologen beperkten zich daarbij tot de psychische funkties van de mens, zoals waarnemen, herinneren en denken ${ }^{3}$ ).

Lewin ging een stap verder. Hij zag ook de verhouding van de mens tot zijn omgeving als een ,gestalte”. Een groep is bijvoorbeeld voor hem geen som van de leden, maar een eenheid met een eigen struktuur en een eigen dynamiek.

Dit dynamisch aspekt is in zijn Amerikaanse tijd een steeds belangrijker rol in zijn beschouwingen gaan spelen. In Amerika bestond al lang een „dynamische psychologie", die niet zozeer uitging van de vermogens en psychische funkties van de mens, alswel van de behoeften en intenties die het gedrag van de mens bepalen. Niet het kunnen, maar het streven van de mens was het uitgangspunt van deze psychologie. Lewin sloot hierbij aan en ontwikkelde een „veldtheorie” waarin de betrokkenheid van de mens op zijn omgeving centraal werd gesteld. De verhouding van de mens tot zijn omgeving zag hij als een ,sociaal krachtveld”. Zijn ideeën hierover uitwerkende, werd Lewin de grondlegger, de „driving genius" "4) van een tak van wetenschap, die bekendheid heeft gekregen als groepsdynamika.

Afkomstig uit de Duitse psychologie, waarin het experiment een belangrijke rol vervulde, volstond Lewin niet met het brengen van theorieën en beschouwingen, maar streefde hij er naar zijn visies experimenteel te toetsen, zoals hij omgekeerd door de uitkomsten van zijn onderzoekingen tot nieuwe koncepties kwam. Lewin was één der eerste sociaal-psychologen die èn experimenteel werkten èn een eigen visie op het sociale gebeuren hadden.

In 1939 publiceerde hij met zijn medewerkers Lippitt en White de resultaten van zijn eerste experimenten over demokratisch en autokratisch leiderschap. Het betrof hier "laboratorium-experimenten" over het ,sociale klimaat” van groepen jongens.

Op deze eerste experimenten, die aan de Universiteit van Iowa werden verricht, zijn vele andere gevolgd, waarbij in de experimentele situatie telkens variaties werden aangebracht.

Vlak voor zijn dood in 1947 bracht Lewin de groepspsychologie ook over naar het bedrijfsleven. In zijn nieuwe funktie aan het Institute of Technology van

m a b blz. 27 
Massachusetts onderzocht hij groepsprocessen in de industrie. Hij konstateerde daarbij dat de autoritaire methoden van leidinggeven weerstanden bij de arbeiders wekten en als gevolg daarvan falen en slechte produktiviteit bewerkstelligden. Werden de arbeiders echter betrokken in het besluitvormingsproces, dan steeg zowel hun plezier in het werk als hun produktiviteit ${ }^{5}$ ).

Deze uitkomsten lopen vooruit op de beschouwingen die wij later bij Argyris en Mc Gregor zullen tegenkomen. Lewin zelf heeft zijn ideeën niet meer voor het bedrijfsleven kunnen uitwerken, terwijl de meesten van zijn direkte leerlingen zich meer met de laboratoriumsituatie dan met de bedrijfssituatie hebben beziggehouden.

Van de diverse onderzoekingen uit de school van Lewin hebben vooral de allereerste bekendheid verkregen. Hoewel de meeste auteurs de beperkte geldigheid van de uitkomsten als een bezwaar noemden en tot voorzichtigheid bij het trekken van algemene konklusies maanden ${ }^{6}$ ), werden de experimenten met veel instemming begroet. Ook in Nederland stonden zij sterk in de belangstelling, zo zeer zelfs, dat in verschillende beschouwingen over leiderschap meer aandacht werd besteed aan de verschillen tussen autokratisch en demokratisch leiderschap dan aan de algemene karakteristika van het leiderschap zelf.

In dit artikel zal het eerste experiment, dat als fundamenteel kan worden gezien, als uitgangspunt worden gekozen. Voor de Nederlandse lezer is dit experiment het beste toegankelijk via het artikel van White en Lippitt in het boek Group dynamics van Cartwright en Zander ${ }^{7}$ ). Voorts werden duidelijke samenvattingen in de Nederlandse taal - voorzien van kritisch kommentaar - geschreven door o.a. Oldendorff 8. 9), Chorus ${ }^{10}$ ) en Van Grunsven ${ }^{11}$ ).

\subsection{Konstruktie van de tegenstelling}

\subsubsection{Opzet van het onderzoek}

Lippitt en White bestudeerden de gedragingen van groepen tienjarige jongens die op verschillende wijze door volwassen leiders werden geleid. Uitgegaan werd van drie wijzen van leidinggeven, die aangeduid werden als respektievelijk autoritair (authoritarian), demokratisch en laissez-faire.

De verschillen hiertussen waren als volgt:

\section{A. Autoritair}

1 Alle beslissingen werden door de leider genomen.

2 Pas op het moment dat de aktiviteiten begonnen, werden deze door de leider voorgeschreven. Deze ging daarbij stap voor stap te werk, zodat de leden van de groep in het onzekere verkeerden over hun toekomstige bezigheden.

3 De leider vertelde alle groepsleden apart wat zij moesten doen en met wie zij moesten samenwerken.

4 De leider was "persoonlijk" in zijn lof en zijn kritiek.

5 De leider deed alleen vóór wat gedaan moest worden, maar werkte verder zelf niet mee.

\section{B. Demokratisch}

1 Alle beslissingen werden na gezamenlijke beraadslaging genomen. De leider moedigde de diskussie aan en hielp deze in goede banen te leiden.

2 Tijdens de diskussie werd het einddoel besproken. Wanneer omtrent de methode waarop dit doel bereikt zou kunnen worden, technische adviezen noodzakelijk waren, bracht de leider twee of meer alternatieven, waaruit een keuze kon worden gemaakt, naar voren. 
3 De leden waren vrij te werken met wie zij wilden. De takkverdeling werd an de groep overgelaten.

4 De leider was objektief en zakelijk in zijn kritiek en lof.

5 De leider gedroeg zich bij de aktiviteiten zovecl mogelijk als een gewoon grocpslid, zonder te veel werk zelf te doen.

C. Laissez-faire

1 De leider beperkte zijn bijdrage tot de besluitvorming tot een mininum. De groep werd hierbij geheel vrij gelaten.

2 De rol van de leider bestond alleen uit het verschaffen van de benodigde materialen on het geven van informatie wannecr hen daarom was gevraagd.

3 Met de taakverdeling bemoeide de leider zich in het geheel niet.

4 Alleen wanneer hem daarom werd gevraagd, gaf de leider kommentaar op de verrichte prestaties.

5 De leider deed geen poging decl te nemen aan de werkzanmheden.

De leiders kregen van te voren gelegenheid zich in te leven in de stijl van leidinggeven die van hen werd gevraagd, terwijl tevens het experiment zo werd ingericht, dat de grocpen na verloop van tijd veranderden van leider en daarmee van type van leidinggeven.

\subsubsection{Uitkomsten van het onderzoek}

De uitkomsten werden door White en Lippitt in een zestal punten samengevat:

1 De verschillen tussen de demokratisch geleide groep en de laissez-faire-groep lagen vooral hierin, dat de prestaties van de laissez-faire-groep in kwantitatief en kwalitatief opzicht achterbleven, dat de leden van deze groep meer speelden dan werkten en dat zij minder waardering hadden voor hun leider.

2 Het belangrijkste verschil tussen de demokratisch en de autokratisch geleide groep lag in de betere ,gemotiveerdheid" voor het werk bij de leden van de demokratisch geleide groep. Dit bleek bijvoorbeeld als de leider even weg was. Ook toonden deze leden een grotere originaliteit. Daarentegen was bij de autoritair geleide groep de kwantiteit van de prestatie iets groter.

3 In de autoritair geleide groep ontstond de meeste vijandigheid en agressie. Ook werden hier de meeste zondebokken gevonden.

4 In de autoritair geleide groep bleken de leden het minst tevreden.

5 In de autoritair geleide groep toonden de leden zich het afhankelijkst en het minst zelfstandig. De individuele verschillen tussen de groepsleden kwamen hier het minst naar voren.

6 In de demokratisch geleide groep ontstond de meeste kameraadschap en het sterkste saamhorigheidsgevoel (group-mindedness).

\subsection{Algemene kritische beschouwing}

In tweeërlei opzicht verdient het hier in het kort weergegeven experiment grote waardering. Allereerst is het alleen al belangrijk vanwege de grote stimulans die het is geweest voor het verrichten van experimentele onderzoekingen op sociaalorganisatorisch gebied. Daarbij komt, dat het experiment op een exakte wijze is opgezet en op een duidelijke wijze is beschreven. Andere onderzoekers kunnen het dientengevolge herhalen en de konklusies op hun juistheid toetsen.

Dit neemt niet weg, dat kritiek zeer wel mogelijk is. Wanneer men met bedrijfsmensen of studenten deze onderzoekingen bespreekt, merkt men, dat bij hen na een eerste verrassing vaak een gevoel van ontnuchtering ontstaat. Aanvankelijk zijn de 
toehoorders geboeid door de opzet en de resultaten, maar na het doordenken van deze resultaten, komen zij met vragen als: ,Wat is nu de betekenis van deze experimenten voor de praktijk?” Of: „Wat hebben wij in het bedrijfsleven eigenlijk aan een dergelijke tegenstelling?".

Ook in de literatuur is kritiek geleverd. Deze kritiek heeft niet betrekking op het genomen initiatief, maar richt zich vooral op de beperkte geldigheid van de getrokken konklusies $6,8,10$ ). Oldendorff gaat nog een stap verder als hij ook de opzet diskutabel stelt. Hij schrijft:

„De sociaal-wetenschappelijke beschouwingen zijn, ondanks het oprechte streven der geleerden naar een zuivere objektiviteit, zelden geheel vrij van politick-ideologische onderstromingen. In de Verenigde Staten is "democracy" zelfs meer dan een politicke onderstroom, men zou het welhaast een religie kunnen noemen; in elk geval een "way of life", een praktische levensphilosophie. Men ontkomt moeilijk aan de indruk dat de vooropgestclde overtuiging van de juistheid der demokratische verhoudingen, leefgewoonten en idealen een zekere rol heeft gespeeld bij het ontwerpen van verschillende laboratoriumexperimenten."

\section{Oldendorff spreekt daarna over het taalgebruik en over het onverantwoord} generaliseren der konklusies:

„Zolang de onderzockingsresultaten op wetenschappelijk verantwoorde wijze ... worden gehanteerd, maken wij weinig principiële bezwaren. Het gevaar ontstaat, wanneer de konklusies gegeneralisecrd worden en wanneer op grond daarvan tot praktische toepassingen wordt overgegaan".

"De wetenschappelijke onderzockers beschrijven voor het overgrote deel op gewetensvolle en zelfs haast scrupuleuze wijze tot in détails de kondities van het experiment en de variabelen welke zij invoeren. Maar in de geesteswetenschappelijke sektor heeft zich nog geen terminologie ontwikkeld welke buiten de dagelijkse spreektaal staat, hetgeen b.v. bij de chemie het geval is. Wanneer de onderzockingsrcsultaten nu in min of meer populaire vorm worden gepubliceerd ... worden gebruikelijke termen, zoals autoritair en demokratisch, niet steeds begrepen in de exakte betekenis welke daaraan in het experiment is toegekend, maar in de vage betekenis, die de sprecktaal daaraan hecht $\left.\ldots{ }^{12}\right)^{\prime \prime}$.

Oldendorff merkt voorts op, dat de experimenten van Lewin c.s. slechts betrekking hebben op een bepaalde konk rete situatie met een bepaalde groep van mensen met een bepaalde mentaliteit, waarbij autoritair en demokratisch een bepaalde inhoud hebben gekregen. Uit deze experimenten mag men niet konkluderen dat in alle situaties met alle soorten mensen alle wijzen van demokratisch leidinggeven de voorkeur verdienen boven alle soorten wijzen van leidinggeven die men autoritair zou kunnen noemen. Als voorbeeld noemt Oldendorff de ondernemer die een oekase uitvaardigt dat het voortaan volstrekt verboden is autoritair op te treden, en de militaire operatie waarbij de strategische plannen op de door Lewin als demokratisch beschreven wijze door de manschappen zouden worden bediskussieerd. Oldendorff meent dat de kans op mislukken dan groot is.

Deze bezwaren, die zoals gezegd niet alleen door Oldendorff maar ook door diverse andere auteurs naar voren zijn gebracht, kunnen misschien nog nader worden uitgewerkt. In de volgende paragrafen is getracht de vinger te leggen op de zwakke plekken in de opzet en het betoog van Lewin c.s. Achtereenvolgens zullen zes konkrete bezwaren worden behandeld. 


\subsection{Uitwerking der bezwaren}

\subsubsection{Meer suggereren dan zeggen}

Oldendorff's bewering dat de wetenschappelijke onderzoekers voor het overgrote deel op "gewetensvolle en zelfs haast scrupuleuze" wijze hun experimenten beschrijven, gaat zeker op voor het hier beschreven onderzoek. White en Lippitt zijn inderdaad bizonder voorzichtig in hun formuleringen. De termen waarin zij hun konklusies mededelen zijn veel behoedzamer gekozen dan de in de hier gegeven samenvatting gebezigde. Hun tweede konklusie luidt in eerste instantie alleen: "Democracy can be efficient". Hun derde is eveneens heel voorzichtig gesteld: "Autocracy can create much hostility and aggression ...". En hun vierde houdt niet meer in dan: „Autocracy can create discontent that does not appear on the surface".

Toch moet deze voorzichtigheid en bescheidenheid voor een deel als schijn worden beschouwd. Zouden deze onderzoekers werkelijk niet meer willen poneren dan alleen dat demokratie efficient kán zijn, dat autokratie vijandigheid en ontevredenheid kàn wekken, enz.?

Als deze onderzoekingen niet meer pretentie zouden hebben dan deze beweringen experimenteel te staven, zouden zij vermoedelijk niet zo'n grote bekendheid hebben gekregen. Het is nuttig en ook prettig te vernemen dat wetenschappelijk is aangetoond dat de demokratie efficient kàn zijn, maar opzienbarend is deze uitkomst toch allerminst. Noch in Amerika noch in Nederland noch in andere landen waar een demokratisch bestel al jaren funktioneert, zullen velen een andere uitkomst hebben verwacht.

Wat veel belangrijker is - en dit verklaart ook de grote aandacht die aan deze onderzoekingen is geschonken -, is dat in de beschreven experimenten het demokratische leiderschap superieur bleek aan het autoritaire. Dit wordt wel niet in deze woorden gezegd, maar de gehele wijze van presentatie laat nauwelijks een andere konklusie toe.

Bovendien beperken de onderzoekers zich niet volledig tot hun experimentele situatie. Zij leggen zelf verbanden tussen deze situatie en verschillende situaties uit het gewone leven. White en Lippitt merken bijvoorbeeld op: „Since arguments for autocracy often take the form of claiming that democracy is not efficient enough to accomplish a certain end (such as winning a war, reducing production costs, or educating a child in necessary basic skills), it is of interest to consider the degree of efficiency of the democratic groups in our experiment" 13).

Men kan zich er dan niet van af maken met te zeggen, dat de wetenschappelijke onderzoekers exakt en voorzichtig zijn, terwijl andere, onkritische popularisatoren op een onverantwoorde wijze hebben gegeneraliseerd. Deze generalisaties worden hun wel erg in de mond gelegd.

\subsubsection{Waardebeladen termen kiezen}

Een ernstiger bezwaar is te maken tegen de termen die door Lewin c.s. zijn gekozen. Ook deze zijn geen toonbeeld van voorzichtig woordgebruik.

$\mathrm{Al}$ is er, zoals Oldendorff aangeeft, in de sociale wetenschappen geen terminologie ontwikkeld die buiten de dagelijkse spreektaal staat, toch is het gewenst zo 
min mogelijk begrippen te gebruiken die emotioneel een bepaalde kleur hebben. Lewin c.s. echter gebruiken deze begrippen niet alleen incidenteel, maar zij kiezen deze zelfs als uitgangspunt van hun studies.

Bij termen als demokratisch en autokratisch blijft men namelijk niet emotioneel neutraal. Men kiest al op de voorhand partij. Ook al beschrijft men de experimentele situatie in nog zulke emotioneel waardevrije termen van objektief konstateerbaar gedrag, toch heeft reeds een emotioneel positiekiezen plaats gevonden. Al worden de demokratisch en autokratisch geleide groepen nog zo onemotioneel beschreven, de resultaten zullen niet met dezelfde welwillende aandacht worden gelezen. In het ene geval zullen zij - bewust of onbewust - kritischer, in het andere geval milder worden beoordeeld.

En niet alleen bij de lezer is dit het geval. Ook de deelnemers aan een dergelijk experiment zullen, wanneer zij deze termen vernomen hebben, hun gedrag mede hierdoor laten bepalen. Zo kon de schrijver van dit artikel bij een soortgelijk experiment als dat van Lewin c.s. bij de demokratische groep een ,noblesse-obligementaliteit" konstateren. De wetenschap dat de groep „demokratisch" was, was op zichzelf al een prikkel voor de leden om een extra prestatie te leveren. Daarentegen meende de leider van de autokratisch geleide groep, wetend dat hij "autoritair" moest optreden, een onaangename rol te moeten spelen. Dit had tot gevolg dat hij mensen de mond ging snoeren, ging vitten, snauwen, onheus bejegenen, ook daar waar dit strikt genomen niet nodig was. Zijn hele toon van spreken klonk op zichzelf al onplezieriger dan anders het geval was. Al zullen er onder leiders die van nature autoritair zijn, ongetwijfeld bullebakken van het voorgestelde type te vinden zijn, noodzakelijk is een dergelijk optreden niet.

Wil men werkelijk twee sociale klimaten op een wetenschappelijk verantwoorde wijze met elkaar vergelijken, dan zal men er goed aan doen geen termen als demokratisch en autokratisch te kiezen, maar zich te beperken tot het beschrijven van de gedragingen der groepsleden in exacte, objektieve, emotioneel zo weinig mogelijk "geladen" termen van gedrag.

\subsubsection{Aaneenkoppelen van kenmerken die niet noodzakelijkerwijze bij elkaar horen}

Met het laatste bezwaar hangt een ander nauw samen.

Demokratie is in het gewone leven een vaag begrip, waaraan door verschillende mensen een verschillende inhoud wordt toegekend. J. van de Giessen zegt hierover in zijn dissertatie over de opkomst van het woord demokratie als leuze in Nederland: „Demokratie is hèt modewoord van de tegenwoordige tijd. Zij is een alom bejubeld ideaal, een leuze, waarvan alle partijen, van uiterst links tot uiterst rechts, gebruik maken. Doch juist hierdoor bestaat er over dit woord ook zoveel meningsverschil en verwarring". ${ }^{14}$ ).

Verschillende groeperingen achten uiteenlopende kenmerken voor de demokratie essentieel. Als zodanig noemt Van de Giessen o.a. volksheerschappij, meerderheidsregering, respektering van de minderheid, vrijheid van meningsuiting, geestelijke vrijheid in wijder verband, gelijkheid voor alle burgers en medezeggenschap.

Uiteraard zijn over de mate van bijvoorbeeld vrijheid, gelijkheid en medezeggenschap weer allerlei opvattingen mogelijk. Bovendien zouden nog verschillende 
andere kenmerken als typerend voor het demokratisch staatsbestel kunnen worden beschouwd.

Uit deze kenmerken kiezen Lewin c.s. er vijf. Op vijf punten verschillen hun autoritaire en demokratische manier van leidinggeven van elkaar. De verschillen hebben betrekking op de beslissingsbevoegdheid, de duidelijkheid van het toekomstperspektief voor de leden van de groep, de vrijheid van partnerkeuze, de manier van beoordelen en de mate waarin de leider aan het uitvoerende werk deelneemt.

Dat de onderzoekers deze kenmerken en geen andere gekozen hebben, is tot op zekere hoogte hun goed recht. Wanneer zij duidelijk omschrijven wat zij irt hun experimenten onder demokratisch en autokratisch verstaan, kan tegen deze wijze van werken geen bezwaar worden ingebracht, ook nict als men zelf iets aridere kriteria voor de tegenstelling demokratisch-autokratisch essentiëler zou ach+en.

Wèl is een bezwaar, dat de suggestie wordt gewekt dat een aantal verschijnscien onlosmakelijk met elkaar is verbonden. Kennelijk zien Lewin c.s. het ene kennerk als een uitvloeisel van, althans als nauw verwant aan het andere. De auteurs gevoclen geen noodzaak hierop kommeritar te geven en te motiveren waarom zij juist deze kenmerken hebben gekozen. Misschien ook zijn zij er zo van overtuigd dat hiermee de kern van de tegensteliing demokratisch-autokratisch leidinggeven is geraakt, dat geen toelichting meer van node is.

Toch is hun opvatting niet vanzelfsprekend. De genoemde verschijnselen behoeven niet per se bij elkaar te behoren. Het is bijvoorbeeld mogelijk dat leiders die zelf alle beslissingen nemen zonder de groepsleden geraadpleegd te hebben, wel deze leden een doel voor ogen houden of wel zakelijk zijn in hun kritick. Eén der beruchtste autokratische leiders, Hitler, nam zijn beslissingen op een vrijwel volledig ,autoritaire" wijze, maar hij toverde zijn volgelingen wel een doel voor ogen.

Misschien zullen nieuwe experimenten aantonen, dat in diverse sociale situaties de door Lewin c.s. gekozen kenmerken vaak met elkaar samengaan. Maar zelfs wanneer een dergelijke positieve korrelatie gevonden zou worden, dan nog mag men niet suggereren dat deze kenmerken noodzakelijkerwijze aan elkaar zijn verbonden.

Hier is sprake van een ,koppelverkoop" waardoor het gestelde probleem ondoorzichtiger wordt gemaakt dan wenselijk is.

Het hier aangevoerde bezwaar is zeker niet alleen van theoretisch-principiële aard. Juist voor de praktijk zou het nuttig zijn in diverse situaties de invloed van de verschillende komponenten van wat Lewin c.s. onder demokratisch verstaan, apart te onderzoeken. Men zou moeten proberen in deze experimenten slechts één der faktoren te laten variëren en de andere konstant houden.

Het is bijvoorbeeld niet uitgesloten dat er in ondernemingen situaties zijn waarin het demokratische leiderschap - zoals door Lewin c.s. gedefinieerd - effektiever werkt en minder frusterend is voor de leden dan het ,autokratische", maar dat een mengsel van beide - dus een konstruktie waarin bepaalde autokratische kenmerken gekombineerd worden met bepaalde demokratische - weer beter voldoet dan het „demokratische” in zijn geheel.

Uiteraard vraagt dit een zeer verfijnde onderzoekingsmethodiek. Maar gaat men tot dit soort experimenten over, dan kan men tot resultaten komen die meer betekenen dan vage algemeenheden en die voor de praktijk van het werken met groepen in ondernemingen van nut kunnen zijn. 


\subsubsection{Abstrakties als realiteiten beschouwen}

Dat deze ,koppelverkoop" tot stand is gekomen, hangt samen met het vermoedelijke uitgangspunt van Lewin. Lewin wil namelijk niet de betekenis van een aantal variabelen nagaan, maar hij wil de tegenstelling demokratisch-autokratisch in zijn algemeenheid diskutabel stellen. Het gaat hem er niet om of de ene of de andere manier van beslissingen nemen of van kritiseren beter is; wat hij wil, is de waarde van „demokratisch” en ,autokratisch” bepalen. Daarmee kent hij echter aan de termen demokratisch en autokratisch een vastere, definitievere betekenis toe dan wetenschappelijk juist moet worden geacht.

De sociale werkelijkheid is veelzijdig en gekompliceerd van aard. Vele verschijnselen spelen voortdurend door elkaar. Dit geldt ook voor de verschijnselen die door Lewin c.s. als demokratisch en autokratisch zijn beschreven. Demokratie en autokratie in reinkultuur treft men vrijwel nergens aan. In alle organisaties, of het nu bedrijven, kerkelijke organisaties, vakverenigingen of sportklubs zijn, vindt men een mengsel van demokratische en autokratische methoden, vaak in een zeer subtiele dooreenstrengeling.

Op zichzelf is het een goed recht van de experimentator om in deze veelvormigheid orde te brengen door een aantal facetten die hem interessant lijken, uit dit moeilijk grijpbare komplex te lichten en nader te onderzoeken. Dan is het echter noodzakelijk, dat hij beseft dat hij een abstraktie van de realiteit, een gedachtenkonstruktie onderzoekt en niet de realiteit zelf.

De vraag is of Lewin c.s. zich hiervan voldoende rekenschap geven. $Z_{i j}$ zien de vijf genoemde kenmerken nict als variabelen, maar als uitingen van een syndroom dat voor hen een realiteit vertegenwoordigt. Zoals onder verkoudheid een komplex wordt verstaan van bijeenhorende uitingen als hoesten, niczen, hees praten e.d., zo beschouwen zij demokratie als een komplex van met elkaar samenhangende verschijnselen.

Hiermee sluiten zij aan bij een alom verbreide opvatting. In de tegenwoordige tijd zijn door de massamedia de meeste mensen zo vertrouwd geraakt met deze begrippen, dat demokratie en autokratie voor hen realiteiten zijn geworden. $\mathrm{Zij}$ beschouwen daarbij bepaalde, konkrete konstellaties waarin zij leven, als typisch demokratisch, andere weer als typisch autokratisch. Daarbij gaan zij echter niet na of zij met demokratisch en autokratisch hetzelfde bedoclen als andere mensen die deze woorden ook gebruiken. Ook zullen zij geen onderscheid maken tussen hun koncepties en datgene wat Lewin c.s. democracy on autocracy noemen.

Gezegd moet worden, dat Lewin c.s. heel weinig doen om de lezers op andere gedachten te brengen. Zij spreken over demokratisch en autokratisch alsof het gaat om duidelijke, scherp van elkaar gescheiden klimaten, die ook buiten de experimentele situatie in de realiteit van het gewone leven op dezelfde wijze voorkomen. Uit het in 1.4.1 vermelde citaat van White en Lippitt bleek dit reeds.

In het begin van het betreffende artikel zeggen deze onderzoekers: „The actual meaning of the adjectives used to label these social climates is necessarily somewhat different from the meanings attributed to them in political and economic discussions" ${ }^{15}$ ). In het verdere betoog echter is nergens te merken dat de auteurs zich van deze verschillen bewust blijven. Er wordt over mogelijke verschillen in betekenis tussen het operationeel gedefinicerde begrip democracy in de experimentele situatie en een eventuele andere betekenis van dit begrip in de levenssituaties niet 
meer gerept. Terwijl andere auteurs, zoals Sherif ${ }^{16}$ ) en Young ${ }^{6}$ ), bij de besprekingen van Lewins experimenten deze woorden tussen aanhalingstekens plaatsen, maken White en Lippitt zelf geen enkele restriktie meer. Nergens vermelden zij verder dat hun resultaten betrekking hebben op een bepaalde abstraktie van een zeer gekompliceerde sociale werkelijkheid - een abstraktie die eventueel ook door een andere zou kunnen worden vervangen.

\subsubsection{Tegenstellingen op de spits drijven}

Het samenvoegen van diverse variabelen heeft nog een tweede gevolg: de tegenstellingen worden groter dan zij in de werkelijkheid meestal zijn. Onder autokratisch worden vijf kenmerken samengebracht die door de hedendaagse westerse mens negatief worden gewaardeerd. Onder demokratisch daarentegen worden vijf kenmerken samengevoegd die stuk voor stuk als positief worden beschouwd. Overleg, inzicht verstrekken in de plannen, vrijheid van partnerkeuze, objektieve en zakelijke kritiek, in redelijke mate zelf meewerken door de leiders, al deze beginselen worden immers door vrijwel ieder als gunstiger beschouwd dan de hieraan tegengestelde principes.

Kombineert men nu enerzijds vijf „goede” en anderzijds vijf „,slechte” principes, dan ontstaan situaties waarin de tegenstellingen wel erg groot worden.

Daarbij komt, dat de fijnere nuances, waar men juist in het dagelijks leven veel mee te maken heeft, ontbreken. De onderzoekers denken in vrij sterke mate in wit en zwart. Of er is totaal geen overleg of er is veel overleg. Of over alles wordt beraadslaagd of over niets. Of er is totale vrijheid van partnerkeuze of er is geen enkele vrijheid.

Uiteraard heeft de wetenschappelijke onderzoeker die van de werkelijkheid abstraheert, het recht om deze tegenstellingen zo scherp te konstrueren. Om de zaken duidelijk te stellen, mag hij van extremen uitgaan.

De waarde van deze onderzoekingen voor de praktijk wordt echter door deze werkwijze beperkt. Het kenmerkende van de meeste situaties uit het dagelijkse leven is immers, dat zovele overgangen voorkomen. Vaak neemt een leider (,autoritair") beslissingen nadat hij (,demokratisch") overleg heeft gepleegd en laat hij van de situatie afhangen in hoeverre en met wie hij overleg pleegt. Een andere keer houdt de leider zich op de achtergrond en laat hij de groep (,,demokratisch") een beslissing nemen, echter nadat hij dank zij zijn (,autokratische") positie een en ander zo heeft voorbereid, dat het een uitgemaakte zaak is dat de groepsleden „zijn” beslissing zullen nemen.

Als kunst van het leidinggeven wordt in de praktijk veelal gezien niet het òf autokratisch of demokratisch te werk gaan, maar het bereiken van een optimaal resultaat door menging van beide uitersten.

In de praktijk bestaat vooral behoefte aan sociaal-wetenschappelijk onderzoek dat zich richt op het vinden van dit optimale resultaat in allerlei levenssituaties. Meer dan aan de globale konstatering dat de ene extreme situatie die men in de praktijk wel eens benadert maar vrijwel nooit bereikt, in vele opzichten superieur is aan een andere extreme situatie die welhaast een karikatuur is van wat men in de praktijk tegenkomt, is er behoefte aan onderzoekingen die betrekking hebben op de "gematigder" situaties die wij dagelijks in de ondernemingen ontmoeten.

In de laatste jaren zijn deze op de praktijksituatie gerichte onderzoekingen - die

m a b blz. 35 
meestal minder spektakulair zijn en daardoor minder de aandacht hebben getrok$\mathrm{ken}$ dan die van Lewin c.s. - vooral in Amerika, maar ook een enkele maal in Nederland ${ }^{17}$ ) uitgevoerd. Dat Lewin c.s. door hun initiatief deze ,veldexperimenten" in praktijksituatics hebben voorbereid, is misschien als hun belangrijkste verdienste te beschouwen.

\subsubsection{De middenpositie kiezen}

Tot dusver is in deze kritische beschouwing alleen gesproken over de tegenstelling autokratisch-demokratisch. Lewin brengt echter nog een derde gedragspatroon ter sprake dat hij anduidt als laissez faire.

Dit laatste ,sociale klimaat" komt in zijn studie iets minder uit de verf dan de beide andere typen. De oorzaak hiervan is dat de karakteristika van dit klimaat voor het overgrote deel in negatieve zin worden geformuleerd. Het leiderschap wordt hier als het ware bepaald door het ontbreken van leiding. De leider geeft namelijk géén kommentaar, verricht géén werk, hecft géén bemoeienis met de taakverdeling, enz.

Toch is in Lewin's betoog de toevoeging van het laissez-faire-type belangrijk. Hierdoor komt namelijk het gedragspatroon waarnaar Lewin's voorkeur uitgaat, centraal te liggen.

Op deze wijze ontstaat een konstruktie die men in tendentieuze beschouwingen wel meer tegenkomt. In veel stellingnemende betogen streven de auteurs er naar een middenpositie in te nemen.

Trouwens in het hele leven is deze positie ,gezocht”. Niet altijd is hierbij van een opzettelijke konstruktie sprake. Van nature is de mens al geneigd zijn eigen positie te vergelijken met wat er om hem heen gebeurt en dan naar twee richtingen te kijken. Experimenten over het ,perspektivisch karakter van de sociale ruimte” toonden bijvoorbeeld aan, dat de mensen hun eigen positie als centraler beschouwen dan deze door anderen wordt gezien ${ }^{18}$ ).

In tendentieuze geschriften wordt deze centrale positie echter meestal wel opzettelijk ingenomen. De schrijvers plaatsen het door hen gepropageerde standpunt graag tussen twee extremere standpunten in.

Uit de vele voorbeelden kiezen wij de verdediging van het theïsme door I. J. M. v. d. Berg. Deze filosoof zegt in zijn Apologetische Cursus, na het atheïsme, dat het Godsbestaan ontkent, besproken te hebben, dat hiertegenover staat het pantheïsme dat in het andere uiterste vervalt door alles met God te vercenzelvigen ${ }^{19}$ ). Pas daarna komt hij tot het theïsme dat nu een centrale positic heeft gek regen.

In hetzclfde geschrift wordt deze werkwijze meer toegepast. Zo wordt vermeld, dat de deterministen de vrije wil loochenen, maar de liberalen het vrijheidsbegrip overdrijven en de absoluto vrijheid van de mens willen. Daartussen, staat onze opvatting" ${ }^{20}$ ).

Via these en antithese komen de schrijvers zo tot een synthese. Hierdoor suggereren zij dat hun standpunt omvattender is dan dat van anderen. Tevens gaat van de centrale positie de suggestie uit, dat het ingenomen standpunt gematigd is, terwijl anderen in hun opvattingen extremer zijn. Dit maakt de indruk van redelijkheid en wekt daardoor vertrouwen. Op de achtergrond ligt het idee van ,de waarheid zal wel in het midden liggen" of, mooier nog, dat van de harmonie der tegendelen.

Van de in deze serie artikelen te behandelen koncepties, is die van Lewin de enige, die van een driedeling uitgaat. Terwijl de andere te behandelen sociaal- 
wetenschappelijke onderzoekers de konstruktie waaraan zij de voorkeur geven, plaatsen tegenover één andere die als het tegendeel wordt beschouwd, verschaft Lewin aan het „sociale klimaat” waarvan hij de waarde wil aantonen, een middenpositie.

Ook hierbij moet men niet vergeten, dat deze positie niet in de werkelijkheid zelf ligt. Andere indelingen zijn eveneens mogelijk, zelfs indelingen waarbij het demokratisch leiderschap een extreme positie inneemt. Men zou bijvoorbeeld ook kunnen experimenteren met drie groepen, die men zou kunnen aanduiden als respektievelijk demokratisch, verlicht despotisch en fascistisch. In dat geval zou het verlicht despotisme een ,gunstige" middenpositie en de demokratie een ,ongunstige" extreme positie innemen.

\subsection{Slotopmerking}

Zoals gezegd is het geenszins de bedoeling van deze kritische beschouwing geweest de genoemde experimenten en beschouwingen als onjuist, waardeloos of overbodig te kwalificeren. De bedoeling is slechts enerzijds aan te tonen dat de experimenten minder wetenschappelijk-objektief zijn dan zij schijnen, anderzijds de relatieve waarde ervan voor de praktijk naar voren te brengen.

Getracht is:

1 aan te tonen dat Lewin c.s. niet een „neutraal” experiment hebben uitgevoerd, maar dat hun onderzoek een strekking had die veel verder reikte dan het experiment zelf; in dit opzicht kan men het onderzoek ,tendentieus" noemen;

2 duidelijk te maken hoe het komt, dat het onderzoek, ondanks een attraktieve presentatie, voor de praktijk weinig direkt nuttig resultaat heeft opgeleverd.

Tevens is geprobeerd aan te geven hoe de onvolkomenheden in Lewin's opzet kunnen worden ondervangen. Er is - zoals uit nieuwere onderzoekingen ook al is gebleken - een degelijkere, betere opzet mogelijk. Deze betere opzet zal aan de ene kant minder algemeen en daardoor minder omvattend zijn, aan de andere kant emotioneel de mensen minder aanspreken. Daardoor zal ook minder de interesse van een groot publiek worden getrokken. Hiertegenover staat echter dat suksessen behaald kunnen worden die minder ,goedkoop" zijn dan die van Lewin c.s.

\section{LITERATUUR}

1 F. P. J. van Grunsven - Psychologie van het bedrijf - Amsterdam/Brussel, 1964 - blz. 66 e.v.

2 De opleiding van de bedrijfspsycholoog - NIPP-mededelingen, no. 157, 8 augustus 1964 blz. 11.

3 Vgl. W. Köhler - Gestalt-psychologie - Vert. v. Schilfgaarde - Utrecht, 1951.

Hierin worden ook enkele oudere onderzoekingen van Lewin besproken (blz. 232 e.v.).

4 H. Bonner - Group dynamics. Principles and applications - N. York, 1959 - blz. 4.

$5 \mathrm{~K}$. Lewin - Resolving social conflicts - N. York, 1948 - blz. 125 e.v.

6 Zie bv. K. Young - Handbook of social psychology - Londen, 1946 - blz. 244 e.v.

7 R. White en R. Lippitt - Leader behavior and member reaction in three ,social climates" - In: D. Cartwright en A. Zander - Group dynamics. Research and theory - Londen, 1954 blz. 585 e.v.

8 A. Oldendorff - De psychologie van het sociale leven - Utrecht, 1953 - blz. 161 e.v.

9 A. Oldendorff - Mensen onder elkaar - Utrecht/Antwerpen, 1961 - blz. 82 e.v. 
10 A. M. J. Chorus - Grondslagen der sociale psychologie - Leiden, 1953 - blz. 475 e.v.

11 F. P. J. van Grunsven - 1.c. - blz. 98 e.v.

12 A. Oldendorff - De psychologie van het sociale leven - Utrecht, 1953 - blz. 165, 166.

13 R. White en R. Lippitt - l.c. - blz. 598.

$14 \mathrm{~J}$. van de Giessen - De opkomst van het woord demokratie als leuze in Nederland. Diss. Utrecht - Den Haag, 1948 - blz. 1.

15 R. White en R. Lippitt - l.c. - blz. 585.

16 M. Sherif - An outline of social psychology - N. York, 1948 - blz. 112 e.v.

17 H. J. J. van Beinum - Een organisatie in beweging. Een sociaal-psychologisch veldexperiment bij de Postcheque- en girodienst - Leiden, 1963.

18 Zie bv. A. Oldendorff - l.c. - blz. 78 e.v.

19 I. J. M. v. d. Berg - Apologetische cursus. Wijsgerig gedeelte. God onze zorgzame Schepper Utrecht, z.j. - blz. 39 e.v.

20 I. J. M. v. d. Berg - l.c. - blz. 18 en 19. 